\title{
DETEKSI GEJALA KLIMATOLOGIS \\ DAN PEMANTAUAN PERUBAHAN IKLIM GLOBAL DENGAN TEKNIK PENGINDERAAN JAUH
}

\author{
Oleh: \\ Bambang Syaeful Hadi \\ Jurusan Pendidikan Geografi, FISE UNY
}

\section{Abstrak}

Perubahan iklim bisa terjadi secara alami maupun tidak alami. Beberapa faktor yang dapat menyebabkan terjadinya perubahan iklim secara alaml dan tldak alaml antara lain muncuinya bintik-bintuk hitam di permukaan matahari pada setiap periode sebelas tahunan, deforestasi maupun efek rumah kaca. Terjadinya akumulasi panas/energi di atmosfer bumi yang berlebihan merupakan dampak dari perubahan iklim. Hal ini mendorong iklim global untuk melakukan penyesuaian dengan peningkatan temperatur bumi.

Teknik penginderaan jauh telah mampu memberikan kontribusi dalam studi iklim dan lingkungan global. Melalui teknik penginderaan jauh berbagai gejala klimatologis di atmosfir dapat diketahui secara cepat. Fenomena klimatologis yang dapot dipelajari melalui rekaman penginderaan jauh meliputi tutupan dan gerakan awan, analisis medan angin, analisis uap alr, struktur temperatur atmosfir, radiasi permukaan, den estimasi cuaca ekstrim. Untuk pemantauan kemungkinan terjadinya perubahan iklim global, maka interpretasi variabel klimatologis secara global dapat dilakukan dengan memanfaatkan berbagai citra satelit dalam berbagai skala, waktu perekaman, dan spektral.

Kata kunci: gejala klimatologis, iklim global, teknik penginderaan jauh

\section{Pendahuluan}

Pemanasan global memang bukan isu baru, tetapi belum munculnya kesadaran kolektif umat manusia dan proses pemanasan yang 
Deteksi Gejala Klimatologis dan Pemantauan Perubahan lklim Global dengan Tekuik Penginderaan Jauh

terus menerus dilakukan oleh sekelompok manusia (negara) akibat mengejar pertumbuhan dan kesejahteraan dirinya menyebabkan isu ini selalu aktual. Isu itu kini telah bergeser pada bagaimana mengatasi perubahan tersebut dan bagaimana mengelola perubahan tersebut. Berbagai upaya terus dilakukan oleh kelompok masyarakat (LSM) dan negara-negara yang memiliki kepedulian telhadap masa depan umat manusia dan ekologinya.

Pada tahun 1988, Badan PBB untuk lingkungan (United Nations Enviroment Programme) dan organisasi meteorologi dunia (World Meteorology Organization) mendirikan sebuah panel Forum AntarPemerintah mengenai Perubahan $\mathrm{klim} /$ Intergovernmental Panel on Climate Change (IPCC), yang terdiri atas 300 lebih pakar Perubahan Iklim dari seluruh dunia. Pada tahun 1990 dan 1992, IPCC menyimpulkan bahwa penggandaan jumlah Gas Rumah Kaca di atmosfer mengarah pada konsekuensi serius bagi masalah sosial, ekonomi, dan sistem alam di dunia. Selain itu, emisi Gas Rumah Kaca yang dihasilkan dari aktivitas manusia juga memberikan kontribusi pada Gas Rumah Kaca alami dan akan menyebabkan atmosfer bertambah panas. Diperkirakan penggandaan emisi Gas Rumah Kaca akan menyebabkan Pemanasan Global sebesar 1,5 - 4,5 derajat Celcius.

Laporan dan analisis dari 441 ilmuwan IPCC yang dikeluarkan pada 6 April 2007 di Brussels menyebutkan bahwa perubahan iklim diperkirakan akan mengakibatkan sekitar 130 juta penduduk Asia kekurangan bahan pangan dan air pada tahun 2050. Pada tahun 2030, frekuensi bencana kekeringan dan banjir diperkirakan mulai meningkat pula di Australia dan Selandia Baru. Dalam Iaporan itu, Achim Stener, Direktur Eksekutif Program Lingkungan PBB mengungkapkan, Asia akan terkena dampak paling berat pada dekade mendatang.

Bila penduduk dunia tidak memperhatikan perubahan ini maka akan menjadi bencana bagi lingkungan dan ekonomi. Lebih dari itu menjadi tragedi kemanusiaan terbesar. Karena itu sangat penting untuk menentukan langkah bersama menghindari dampak perubahan iklim tersebut. Laporan itu menjelaskan pula bahwa setiap kenaikan suhu udara $2{ }^{\circ} \mathrm{C}$ dapat mengurangi tingkat kesuburan padi 5 hingga 12 persen. Ini akan dialami di Tiongkok. Sedangkan menurunnya produksi padi 10-30 persen juga terjadi di Bangladesh pada tahun 2050. Diperkirakan, sekitar 100 juta penduduk Asia akan menghadapi risiko banjir akibat naiknya permukaan air laut 1-3 milimeter tiap tariun (http://www.suarapembaruan.com/News/2007/04/11). 
Situasi ini merupakan sebuah proyeksi. Mereka mengibaratkannya sebagai jalan bebas hambatan menuju kematian. Menurut Andrew Weaver, pakar ikli,n dari Universitas Victoria di British Columbia Amerika Serikat (A૬), kondisi sekarang memang bagai jalan bebas hambatan menuju kematian. Memang masih banyak manusia yang mampu bertahan hidup, tetapi jutaan akan meninggal apabila skenario dalam laporan itu benar terjadi. Para pakar PBB berpendapat, perubahan kondisi alam itu menurunkan kualitas banyak spesies, wilayah pantai, dan orang-orang miskin. Manusia merupakan penyebab munculnya perubahan itu dan ini sudah teriadi lebih dari tiga dekade.

\section{Mengapa Iklim Berubah}

Perubahan iklim bisa terjadi secara sengaja maupun secara tidak sengaja. Perubahan iklim dengan sengaja adalah dengan cara mengubah susurian atmosfer dan campur tangannya dalam faktor-faktor yang mengendalikan keseimbangan panas dan susunan kimianya. Perubahan iklim secara sengaja misalnya dengan membuat hujan buatan. Hal yang mencemaskan adalah perubahan iklim secara tidak disengaja, yang membawa dampak luar biasa terhadap masa depan umat manusia.

Beberapa faktor yang dapat menyebabkan terjadinya perubahan iklim adalah terjadi secara alami dan tidak alami:

1. Munculnya bintik-bintuk hitam pada permukaan matahari pada setiap periode sebelas tahunan

Pernyataan ini baru merupakan hipotesis yang perlu terus diuji kebenarannya. Munculnya bintik-bintik hitam ini sebenarnya terjadi pada setiap periode 7-14 tahun. Teori ini dikemukakan oleh Willet. Menurut pendapatnya, bintik-bintik hitam ini berkorelasi dengan menurunnya suhu permukaan bumi. Bukti yang dikemukakan untuk mendukung teori ini adalah adanya korelasi antara menurunnya produksi panennya petani gandum di AS dengan kemunculan bintikbintik hitâm tersebut. Saat munculnya bintik-bintik hitam itu terjadi perubahan suhu yang menyebabkan gandum tidak dapat berproduksi secara normal. Menurut penyeledikan para ahli astrofisika, aktivitas matahari memang mengalami dinamika.

2. Deforestasi

Salah satu fungsi hutan adalah sebagai penyerap dan pendaur ulang, karbondioksida $\left(\mathrm{CO}_{2}\right) \cdot \mathrm{CO}_{2}$ yang dikeluarkan oleh mesin kendaraan, pabrik-pabrik dan sumber-sumber lainnya dapat didaur ulang oleh tumbuh-tumbuhan, dimana $\mathrm{CO}_{2}$ diperlukan untuk 
berfotosintesis, yang kemudian menghasilkan oksigen $\left(\mathrm{O}_{2}\right)$, dengan demikian hutan berfungsi sebagai paru-paru alam. Kenyataannya pembalakan liar (illegal logging), pembakaran hutan telah merusak jutaan hektar tiap tahunnya. Tingkat laju deforestasi Indonesia adalah 1,8 juta hektar per tahun, yang merupakan rata-rata catatan laju pengrusakan hutan di tanah air antara tahun 2000 hingga 2005. Sebanyak 72 persen dari "intact forest" atau hutan asli Indonesia telah musnah dan setengah dari yang tersisa terancam keberadaannya antara lain oleh penebangan komersil, pembalakan liar (illegal logging), kebakaran hutan, dan pembukaan hutan untuk kebun kelapa sawit (www.antara.co.id/arc/2007/5/3).

Ke depan tampaknya deforestasi ini akan semakin sulit dihindari karena semakin besarnya tekanan penduduk atas lahan hutan. Jumlah penduduk dunia yang semakin besar merupakan ancaman tersendiri, karena penduduk ini akan mempengaruhi pola penggunaan lahan, yang pada gilirannya akan mendesak lahan hutan. Oleh karena itu kebijakan dalam bidang kehutanan di masa mendatang harus lebih protektif agar kehidupan manusia tidak terancam oleh perubahan iklim. Untuk itu Howard (1996) menyarankan perlunya optimalisasi penggunaan metode pemantauan hutan dengan biaya yang memadai. Metode tersebut adalah penginderaan jauh dalam rangka membantu para pengambil keputusan dan penyediaan informasi secara cepat dan baik.

Menurut WWF (2007) aktor manusia sebagai penyebab pemanasan global dan perubahan iklim, terutama aktivitas manusia yang berhubungan dengan penggunaan bahan bakar fosil (minyak bumi dan batu bara) serta kegiatan lain yang berhubungan dengan hutan, pertanian, dan peternakan. Aktivitas manusia di kegiatan-kegiatan tersebut secara langsung maupun tidak langsung menyebabkan perubahan komposisi alami atmosfer, yaitu peningkaian jumlah Gas Rumah Kaca secara global.

Guinness World Records atau Rekor Dunia Guinness, telah memberikan konfirmasi pada Greenpeace bahwa dalam buku rekornya edisi 2008 akan memasukkan Indonesia sebagai negara dengan tingkat kehancuran hutan tercepat di dunia (www.antara.co.id/arc/2007/5/3). Bila hutan ditebang, maka $\mathrm{CO}_{2}$ semakin bertambah, dan oksigen yang diperlukan oleh manusia dan binatang menipis. 


\section{Efek rumah kaca}

Sejak awal jaman industrialisasi, awal akhir abad ke-1\%, konsentrasi Gas Rumah Kaca meningkat drastis. Diperkirakan sej:k tahun 1880 teniperatur rata-rata bumi meningkat $0.5-0.6^{\circ} \mathrm{C}$ akibat emisi Gas Rumah Kaca yang dihasilkan dari aktivitas manusia. Buktibukti terjacinya efek rumah kaca diantaranya adalah: Pertama, menurut teori fisika, beberapa gas mempunyai kemampuan untuk menahan panas. Kedua, pengukuran yang dilakukan sejak tahun 1950an menunjukkan tingkat konsentrasi Gas Rumah Kaca meningkat secara tetap, dan peningkatan ini berhubungan dengan emisi Gas Rumah Kaca yang dihasilkan industri dan berbagai aktivitas manusia lainnya. Ketiga, penelitian menunjukkan bahwa udara yarıg terperangkap di dalam gunung es telah berusia 250 ribu tahun. (www.wwf.or.id).

Efek rumah kaca merupakan analogi dari glass house untuk keperluan pertanian. Dalam rumah kaca sinar matahari bisa masuk, tetapi suhu pada rumah kaca tidak bisa dilepaskan, sehingga suhu di dalam rumah kaca lebih panas dari suhu di luarnya. Demikian halnya dengan bumi, bumi yang dikelilingi atmosfir diibaratkan seperti rumain kaca. Sebetulnya jika tidak terdapat gas-gas yang berbahaya (polutan) pada lapisan atmosfir maka tidak terjadi efek rumah kaca. Emisi karbondioksida $\left(\mathrm{CO}_{2}\right)$, chlorofluorocarbon (CFC), oksida nitrogen darı beberapa gas lainnya yang dilepaskan ke atmosfir sebagai akibat dari aktivitas manusia diduga merupakan faktor yang menyebabkan terjadinya efek tersebut. Secara lebih rinci hal yang menyebabkain timbulnya efek rumah kaca, adalah:

a. Bahan buangan industri (BBI)

$\mathrm{BBI}$ sebagai sisa dari aktivitas industri manusia dibawa angin dan akhirnya terkonsentrasi di atmosfir. Diantara $\mathrm{BBI}$ ini berupa $\mathrm{CO}_{2}$ dan $\mathrm{CO}$, gas iri bertambah banyak, apalagi hutan sebagai pendaur banyak ditebang sehingga $\mathrm{CO}_{2}$ bertambah banyak dan oksigen yang diperlukan untuk pernafasan manusia dan binatang jumlahnyä: semakin menipis.

b. Gas yang ditimbulkan oleh aktivitas organik pada rawa yan:; menghasilkan $\mathrm{CH}_{4}$ (metana). Keberadaan gas rawa secara alami ir: tidak mempunyai pengaruh yang signifikan terhadap efek rumah kaca. Selain itu lahan gambut merupakan penyimpan gas karboli yang sangat besar. Pengelolaan lahan gambut yang salah apalagi sampai terbakar, maka pelepasan gas karbon yang tersimpan 
dalam gambut akan menyumbang gas karbon ke udara jauh lebih parah dari sekedar dampak kebakaran hutan blasa. Menurut estimasi, karbon yang tersimpan dalam lahan gambut jumlahnya lebih dari 30\% jumlah karbon di planet ini.

c. Penggunaan Chlorofluorocarbon (CFC)

CFC juga merupakan Gas Rumah Kaca dan berpotensi terhadap Pemanasan Global jauh lebih tinggi dibanding karbondioksida sehingga dampak akumulasi CFC di atmosfer mempercepat laju Pemanasan Global. CFC akan tetap berada di atmosfer dalam waktu sangat lama, berabad -abad. Artinya, kontribusi CFC terhadap penipisan lapisan ozon dan Perubahan Iklim akan berlangsung dalam waktu sangat lama. CFC digunakan pada beberapa alat pendingin seperti $A C$, kulkas, dan semprotan minyak parfum. CFC pada merk dagang biasa disebut dengar. freon. Lapisan atmosfer merupakan selimut gas yang menutupi bumi. Rumah kaca adalah analogi atas bumi yang dikelilingi gelas kaca. Panas matahari masuk ke bumi dengan menembus gelas kaca tersebut berupa radiasi gelombang pendek. Sebagian diserap oleh bumi dan sisanya dipantulkan kembali ke angkasa sebagai radiasi gelombang panjang. Hanya saja, panas yang seharusnya dapat dipantulkan kembali ke angkasa menyentuh permukaan gelas kaca dan terperangkap di dalam bumi. Layaknya proses dalam rumah kaca di pertanian dan perkebunan, gelas kaca memang berfungsi menahan panas untuk menghangatkan rumah kaca.

Masalah timbul ketika aktivitas manusia menyebabkan peningkatan konsentrasi selimut gas di atmosfer (Gas Rumah Kaca) sehingga melebihi konsentrasi yang seharusnya. Maka, panas matahari yang tidak dapat dipantulkan ke angkasa akan meningkat pula. Semua proses itulah yang disebut Efek Rumah Kaca. Pemanasan global dan perubahan iklim merupakan dampak aari Efek Rumah Kaca.

WWF (World Wild Fund) menyatakan bahwa AS yang merupakan penyembur emisi gas rumah kaca terbesar di dunia, adalah 'penjahat terbesar' dari perubahan iklim. Data terakhir menunjukkan bahwa Amerika Serikat sebagai penyumbang 720 juta ton Gas Rumah Kaca karbondioksida-setara dengan 25\% emisi total dunia atau 20,5 ton per kapita. Emisi Gas Rumah Kaca pembangkit listrik di Amerika Serikat saja masih jauh lebih besar 
bila dibandingkan dengan total jumlah emisi 146 negara (3/4 negara di dunia). Sektor energi menyumbang sepertiga total emisi Gas Rumah Kaca (www.wwf.org). AS (bersama Australia, Tiongkok, dan India) hingga kini belum bersedia meratifikasi Protokol Kyoto, karena dengan meratifikasinya berarti negara tersebut harus menurunkan emisi gas ke atmosfir. Anehnya tindakan AS yang jauh lebih berbahaya bagi keselamatan masa depan umat manusia ini lebih dari sekedar dugaan bahwa Iran sedang mengembangkan energi nuklir, justru tidak ada yang mempermasalahkan.

\section{Dampak Perubahan Iklim}

Terjadinya akumulasi panas (atau energi) di atmosfer bumi yang berlebihan, mendorong iklim global untuk melakukan penyesuaian, di antara penyesuaian tersebut adalah peningkatan temperatur bumi (Pemanasan Global dan berubahnya iklim regional-pola curah hujan, penguapan, pembentukan awan-atau perubahan Iklim). Dampak dari perubahan ikllm tersebut antara lain:

1. Musnahnya berbagai jenis keanekaragaman hayati.

2. Meningkatnya frekuensi dan intensitas hujan badai, angin topan, dan banjir.

3. Mencairnya es dan glasier di kutub.

4. Meningkatnya jumlah tanah kering yang potensial menjadi gurun karena kekeringan yang berkepanjangan.

5. Kenaikan permukaan laut hingga menyebabkan banjir yang luas. Pada taluun 2100 diperkirakan permukaan air laut naik hingga $15-95 \mathrm{~cm}$.

6. Kenaikan suhu air laut menyebabkan terjadinya pemutihan karang (coral bleaching) dan kerusakan terumbu karang di seluruh dunia.

7. Meningkatnya frekuensi kebakaran hutan.

8. Menyebarnya penyakit-penyakit tropis, seperti malaria, ke daerah daerah baru karena bertambahnya populasi serangga (nyamuk).

9. Daerah-daerah tertentu menjadi padat dan sesak karena terjadi arus pengungsian.

10. Mengancam keamanan pangan. (www.wwf.or.id)

Kawasan tropis akan menderita pukulan produksi pangan akibat besarnya variabilitas iklim. Perubahan iklim global yang mulai terjadi saat ini akan menyebabkan kenaikan suhu, naiknya frekuensi dan intensitas kekeringan, banjir, "cyclone tropis" dan angin topan. Hal ini bisa mengencam produksi pangan nasional terutama setelah tahun 2030 (www.wwf.or.id). 
Deteksi Gejala Klimatologis dan Pemantauan Perubahan Iklim Global dengan Teknik Penginderaan Jauh

Masa tanam dan panen padi akan bergeser, bahkan prediksi bisa meleset. Produksi beras akan terganggu, sehingga harus diantisipasi agar tidak terjadi kekurangan. Pengaruh perubahan iklim giobal sudah mulai terasa dengan bergesernya musim tanam dan panen padi di sejumlah negara, termasuk Indonesia, sejak setahun lalu. Produsen utama beras, seperti Vietnam dan Thailand, juga terpengaruh sehingga tidak mudah menjalankan perdagangan beras internasional, termasuk rnenentukan harga dan waktu

pengiriman (http://www.suarapembaruan.com/News/2007/04/11).

Menurut Irving Mintzer dari World Resources Institut, USA sebagaimana dikutip Bayong Tjasyono (1987) bahwa kenaikan suhu pada musim panas di AS pada tahun 1980 menyebabkan lebih 1000 orang meninggal, menimbulkan kerugian pertanian sebesar \$16 billion, meningkatnya pemakaian energi dan kerusakan jalan di mana-mana, membunuh jutaan ayam, frekuensi tornado semakin tinggi, dan gelombang pasang (tidal wave) telah membunuh ribuan penduduk pesisir. Pada dekade terakhir USA direpotkan oleh semakin seringnya terjadi badai besar yang banyak menelan korban nyawa dan harta benda yang tidak sedik.it.

\section{Kontribusi Penginderaan Jauh untuk Studi Iklim dan Lingkungan Global}

1. Studi atmosfir dan iklim

Atmosfir merupakan selubung gas yang menyelimuti bumi, terkendali oleh bumi karena adanya gaya gravitasi penuh bumi. Atmosfir tersusun atas sejumlah gas, yang terdiri dari nitrogen $(78,08 \%)$, oksigen $(20,95 \%)$, argon $(0,93 \%)$, karbondiksida $(0,033 \%)$, dan gas-gas lainnya yang jumlahnya kurang dari 0,033\%. Atmosfir dapat dibagi-bagi stratifikasinya berdasarkan konduktivitas dan struktur termalnya. Berdasarkan struktur termalnya, lapisan atmosfir dibagi menjadi empat, yakni troposfir $(0-12,5 \mathrm{~km})$, stratosfir $(12,5-50 \mathrm{~km})$, mesosfir $(50-80 \mathrm{~km})$ dan termosfir atau ionosfir $(>80 \mathrm{~km})$. Masingmasing perlapisan tersebut dibatasi oleh pause, sehingga lapisan perbatasan atmosfir dinamakan tropopause, stratopause, dan mesopause. Manusia dengan segala aktivitasnya di permukaan bumi berada di lapisan atmosfir terendah, yakni troposfir dinıana gejala meteorologis/ klimatologis, seperti angin, awan, hujan terjadi pada lapisan ini.

Langkah konkrit yang perlu dilakukan untuk mengatasi ancaman pemanasan global adalah dengan mengeliminasi faktor penyebab perubahan iklim global atau paling tidak mengurangi 
intensitas, kuantitas dan kualitas faktor penyebab. Untuk melakukan upaya tersebut memerlukan sejumlah langkah melalui studi yang mendalam/komprehensif dan implementatif.

Salah satu upaya tersebut adalah dengan mengkaji gejala-gejala meteorologis dan klimatologis dengan melakukan pemantauan dan evaluasi. Untuk mengetahui variabilitas kondisi iklim secara global diperlukan data akurat. Perolehan data akurat mengenai gejala meteorologis, 'klımatologis, dan dampaknya baik secara lokal maupun global dapat disajikan secara aktual dan kontinyu melalui rekaman satelit penginderaan jauh (inderaja). Menurut Howard (1996), Penginderaan Jauh sebagai cabang dari disiplin ilmu geografi memiliki arti penting bagi disiplin ilmu lainnya, terutama dalam studi yang memerlukan sifat pantulan/radiasi permukaan bumi. Tidak jarang penginderaan jauh mampu meniberikan data spesifik yang tidak dapat diperoleh dari sumber lainnya. Satelit inderaja yang sengaja didisain untuk pemantauan gejala klimatik diantaranya adalah NOAA (National Oceanic and Atmospheric Administration), TIROS (Televition and Infrared Observation Satellite), DMSP (Defense Meteorological Satellite Program), SMS/GOES (Syncronous Meteorological Satellite) dan ERS. Pemantauan iklim dapat pula dengan menggunakan data satelit lain yakni untuk kepentingan pemantauan regional kondisi hutan dunia yang mana keberadaan hutan ini berperarı dalam perubahan iklim tersebut.

Pada tahun 1981 untuk pertama kalinya data penginderaan jauh digunakan untuk penafsiran sumberdaya hutan, yakni dengan menggunakan citra landsat. 13 negara ESA dan Canada prihatin terhadap kondisi lingkungan meluncurkan ERS untuk keperluan studi lingkungan. Orbit Sinkron matahari, ketinggian $785 \mathrm{~km}$, orbit near polar. Satelit ini digunakan untuk pemantauan temperatur muka laut, angin dan kondisi kelautan, energi gelombang. dimana atmosfir \& laut berinteraksi membentuk gelombang laut. Data yang direkam meliputi kekuatan, arah angin permukaan, tinggi, lereng, dan distribusi spektral gelombang. Dengan demikian model peramalan lebih tepat. Disamping itu satelit ini juga dapat digunakan sebagai alat bantu untuk pembuatan topografi dasar laut yang didasarkan pada topografi permukaan laut. Topogafi permukaan laut mencerminkan topografi dasar laut, ada gunung, lembah, dataran. Air laut bersifat dinamik, terjadi sirkulasi arus, rotasi bumi mempengaruhi menjadi pola sirkulasi, yang dapat 
mempengaruhi iklim bumi. Kegunaan lainnya yang berkaitan dengan laut adalah untuk memantau tinggi muka air laut sebagai akibat dari gelombang pasang maupun greenhouse effect, kenaikan permukaan laut dapat terjadi secara lokal maupun kenaikan global. Hasil pemantauan ini dapat dijadikan sebagai peringatan dini (early warning) bagi niasyarakat pesisir terhadap kemungkinan bahaya banjir pasang. Terapan lainnya adalah untuk penginderaan kutub, dimana kutub menyimpan energi besar yg menentukan kondisi laut (75\% muka bumi merupakan lautan). Fungsl kutub sebagai stabilisator dan pengendali iklim perlu dipantau agar segala perkembangan yang berdampak pada peningkatan volume air laut karena terjadinya pencairan kutub dapat diantisipasi sedini mungkin.

Beberapa fenomena yang berkaitan dengan klimatologis d.an dapat dipelajari melalui rekaman penginderaan jaúh diantaranya adalah:

a. Tutupan dan gerakan awan

Awan merupakan sekumpulan tetes-tetes air yang mempunyai konsentrasi $100 / \mathrm{cm} 3$ dan mempunyal jari-jari tetes sekltar $10 \mu \mathrm{m}$. Tutupan awan dinyatakan dalam persen, tetapl ada juga yang menyatakannya dalam perdelapanan dari langit yang tampak, misalnya: perawanan 0 berartl langit cerah, perawanan 4 berarti separuh dari langit diliputi angin, dan 8 berarti langit tertutup awan (mendung). Tutupan awan dapat dengan mudah diketahui sebaran jenis, ketebalan, dan potensinya untuk menjadi hujan melalui citra penginderaan jauh.

Persentase liputan awan berdasarkan ketinggiannya pada setiap dasaran ataupun bulanan sebagai dasar untuk mengetahui kemungkinan hujan juga dapat diketahui dari citra. Awan rendah (Stratus, Sratocumulus, dan Cumulus Congstus) kemungkinan hanya terjadi hujan gerimis, awan menengah (Altostratus dan Altocumulus) berpeluang untuk menjadi hujan sedang, dan awan tInggl (Cumulonimbus) berpeluang menjadl hujan lebat. Dengan demikian keberadaan sitra penginderaan jauh dapat digunakan untuk membuat ramalan cuaca. Lebih dari itu rekaman satelit ini dapat menyajikan gambaaran kondisi per-awan-an secara global, sehingga kondisi cuaca secara lokal maupun global dapat terpantau secara lebih teliti. 
b. Analisis medan angin

Citra penginderaan jauh yang telah dibuat mozaik atau dirangkai dalam satu program animasi dapat memperlihatkan Eerakan awan. Rangkaian citra tersebut dapat memberikan gambaran vektor gerakan awan. Dari vektor tersebut dapat ini dapat diketahui arah dan kecepatan angin pada level awan tersebut. Citra seperti ini dapat diamati pada rekaman satelit geosyncronous ATS (Application Technology Satellite), Nimbus THR, dan Meteosat. Studi fenomena klimatologis dapat dilakukan pada skala regional dan global.

c. Analisis uap air

Kandungan uap air di atmosfir merupakan parameter penting kondisi cuaca/iklim yang dapat diukur secara langsung dari citra satelit (Lo, 1986). Citra satelit Meteosat memberikan rekaman melalui band uap air (5,7-7,1 $\mu \mathrm{m})$, yang memberikan pandangan menyeluruh mengenai pola uap air pada pertengahan lapisan troposfir. Radiasi yang dipantau berasal dari emisi dalam wilayah 500-250 mb troposfir. Daerah berawan atau banyak mengandung awan dapat dideteksi dengan level yang berbeda. Daerah yang lebih kering menunjukkan rona abu-abu gelap sampai hitam, sementara daerah dengan kondisi uap air lebih banyak akan tergambar dengan rona putih atau abu-abu cerah. Menurut Steranka (dalam Lo, 1986) dergan menghubungkan bayangan abu-abu dengan pengukuran radiosonde, maka analisis yang akurat akan menghasilkan hasil interpretasi stratifikasi vertikal kandungan uap air.

d. Struktur temperatur atmosfir

Pengukuran temperatur atmosfir dari jarak jauh pertama kali dilakukan dengan menggunakan satelit TIROS VII kemudian diikuti oleh SIRS (Satellite Infrared Spectrometer) dan IRIS (Infrared Interferometer Spektometer). Beberapa sensor lain pada generasi berikutnya dipasang pada satelit Nimbus yang melakukan pekerjaan yang sama antara lain SCR, ITPR, HIRS, dan bahkan sensor lain yang dibawa oleh satelit TIROS dan NOAA seperti VTPR (Vertical Temperatur Profile Radiometer), HIRS/2 (High Resolution Infrared Sounder), dan SSU (Stratospheric Sounding Unit). Pada umumnya sensor penginderaan jauh memanfaatkan spektrum inframerah pada panjang gelombang $4,5 \mu \mathrm{m}-15 \mu \mathrm{m}$. Penyelidikan 
dengan penginderaan jauh juga diperluas dengan memanfaatkan spektrometer gelombang mikro, seperti NEMS dan SCAMS.

Menurut Lo (1986) hasil perekaman data temperatur dengan penginderaan jauh mempunyai ketelitian yang hampir sama persis dengan hasil pengukuran dengan menggunakan radiosonde, kecuali pada troposfir tengah dimana pengukuran SIRS sedikit lebih panas.

e. Radiasi permukaan

Studi radiasi permukaan merupakan pengembangan dari hasll pengukuran radiasi dan temperatur. Penentuan radiasi permukaan didasarkan pada karakteristik lahan, vegetasl, dan kelembaban yang berdampak pada albedo permukaan. Albedo permukaan dapat berubah-ubah sesuai dengan bagaimana pengelolaan lahan. Untuk keperluan penghltungan besarnya albedo permukaan para ahli berusaha membuat berbagai model, diantaranya dengan mencari korelasi antara tingkat kecerahan citra dan albedo dengan menggunakan persamaan polinomial.

Aplikasi lainnya yang cukup menarik berkaitan dengan budget radiasi dan temperatur inl adalah untuk studi pulau panas perkotaan (urban heat island). Pulau panas kota terjadi karena gejala urbanisasi, sehingga temperatur udara cenderung naik. Ada perbedaan temperatur udara antara kota dan daerah perdesaan sebagai hinterland dan kota menjadi isoterm tertutup yang terpisah dari medan temperatur pada umumnya. Pulau panas kota mencerminkan perubahan total iklim mikro yang disebabkan oleh perilaku manusia yang merubah permukaan landscape kota. Pemanfaatan berbagai alat pemanas, pengatur udara, pembangkit listrik dan hampir semua permukaan lahán kota telah tertutup baik oleh bangunan, pengeras jalan, jembatan, dan bahan bangunan lainnya yang dapat menyimpan panas matahari dan ketika malam hari maka panas matahari yang tersimpan itu melepaskan panasnya ke lingkungan. Di sini citra penginderaan jauh inframerah dapat menunjukkan tingkatan panas (isoterm) pulau panas kota, sehingga dapat dilakukan penanganan pada titik-titik yang dianggap parah. 
f. Estimasi cuaca ekstrim

Cuaca ekstrim dapat berupa hujan sangat lebat, badai besar (siklon tropis). Satu hal yang perlu diperhatikan berkaitan dengan kemungkinan terjadinya cuaca ekstrim adalah dengan mengamati liputan awan harian diantaranya melalui data Satelit GOES-9 atau MTSAT. Data tersebut diperlukan untuk mengidentifikasi tahap awal pembentukan depresi tropis. Untuk analisis akurat diperlukan dukungan data arah dan kecepatan angin dari stasiun meteorologi.

g. Analisis dan prakiraan cuaca

Berdasarkan data mengenai tipe awan, tutupan awan, tingkat kecerahan, ketinggian dan gerakan awan yang terekam pada citra penginderaan jauh, maka dapat dilakukan analisis tentang kemungkinan terjadinya hujan di daerah yang kondisi awannya telah dianalisis. Prakiraan cuaca yang paling pokok adalah gejala hujan. Cara untuk membuat perkiraan hujan dengan teknik penginderaan jauh diantaranya dapat dilakukan dengan Metode Bristol yang dikembangkan oleh Barret (dalam Lo, 1986). Metode tersebut berupaya menghubungkan data pengukuran hujan dengan data awan dari satelit orbit kutub. Dengan demikian, citra penginderaan jauh dalam hal ini sangat bermanfaat dalam pembuatan prakiraan cuaca.

2. Pemantauan Faktor Penyumbang Perubahan Iklim

Salah satu kelebihan teknik penginderaan jauh adalah kemampuan melihat bola bumi dan selubung atmosfir secara menyeluruh atau global. Oleh karena itu untuk keperluan pemantauan dan evaluasi kondisi klimatologis dalam kaitannya dengan perubahan iklim global, penginderaan jauh memegang peranan teramat penting. Melalui penginderaan jauh berbagai gejala klimatologis yang terjadi di atmosfir dapat diketahui secara cepat dan hemat. Pengukuran secara lokal di tiap negara tentang kondisi atmosfir memerlukan analisis yang rumit untuk dapat mencapai kesimpulan yang bermakna.

Untuk keperluan pemantauan kemungkinan terjadinya perubahan iklim dalam skala global, maka interpretasi variabel klimatologis secara global dapat dilakukan dengan memanfaatkan berbagai citra satelit dalam berbagai skala, waktu perekaman, dan spektral. Beberapa aplikasi penginderaan jauh yang berkaitan secara 
langsung dengan faktor penyebab terjadinya perubahan iklim diantaranya adalah:

a. Pemantauan tutupan vegetasi hutan dunia

Vegetasi hutan dunia sangat menentukan stabilitas iklim dunia. Hutan memiliki manfaat yang banyak. Salah satu hal yang berkaitan dengan iklim adalah segala jenis vegetasinya mampu mengubah karbondioksida menjadi oksigen. Idealnyá pada setlap pulau, landuse/landcover berupa hutan. Keberadaan hutan saat ini semakin terdesak, baik karena pembukaan lahan baru untuk areal permukiman maupun penebangan liar. Studi tentang tutupan hutan dapat diketahui secara baik dengan menggunakan cltra inframerah. Pemantauan terhadap luas hutan dari tahun ke tahun dapat dilakukan dengan citra multitemporal dengan hasil yang sangat teliti. Dewasa ini setiap negara tidak dapat memanifulasi luas hutan miliknya, karena komunitas internasional dapat memantau luasan tutupan hutan dengan memanfaatkan citra inderaja.

b. Pemantauan kebakaran hutan

Kebakaran hutan merupakan peristiwa yang terjadi hampir secara rutin di Indonesia. Kebakaran hutan disamping memusnahkan vegetasi sebagai paru-paru dunia juga menyumbang gas karbon ke udara. Kebakaran hutan di indonesia mampu menyumbang debu sampai ke negara-negara di Benua Afrika. Secara teoritik kebakaran hutan dapat terjadi secara alami maupun buatan. Secara alami hutan terbakar karena adanya embun yang ada pada dahan dan dedaunan yang berfungsi memfokuskan sinar matahari yang mengenainya (berfungsi seperti suryakanta), sehingga terjadi kebakaran (Wisnu Arya Wardhana, 2004). Kenyataannya kebakaran hutan lebih banyak terjadi karena faktor kesengajaan. Para pengusaha nakal yang ingin mendapatkan lahan untuk usaha dengan jalan membakar hutan diantaranya untuk: dikonversi menjadi lahan perkebunan kelapa sawit. Kebakaran hutan dapat dipantau dengan berbagai data inderaja. Aspek yang berkaitan dengan kebakaran hutan yang dapat dianalisis dengan citra inderaja antara lain: Iuas kebakaran, arah kebakaran, sebaran abu/debu, lama kebakaran, jenis hutan yang terbakar. 
c. Pemantauan perilaku lautan dan suhu atmosfir

Perilaku lautan dapat berupa suhu lautan, arus/gelombang laut. Suhu lautan merupakan indikator yang sangat nyata terhadap karakteristik iklim. Perubahan suhu lautan dapat dipengaruhi oleh faktor global perubahan suhu atmosfir. Perubahan suhu atmosfir dapat ditunjukkan oleh gerakan massa udara yang panas atau dingin. Perubahan suhu udara yang tidak lazim karena banyaknya aktivitas manusia yang menghasilkan karbondioksida yang dilepas ke udara dapat menyebabkan gerakan massa udara panas yang dapat mengacaukan kondisi iklim alami, yang dapat ikut menyebabkan suhu lautan menghangat. Kondisi ini mempengaruhi gerakan arus laut yang menjadi tidak semestinya. Pada kondisi tertentu kondisi laut yang hangat ini dapat menjadi ancaman hujan di luar musim, gerakan badai hebat, gelombang tinggi, dan lain-lain. Oleh karena itu rekaman suhu laut yang dapat dipantau dengan rekaman satelit penginderaan jauh dapat menjadi bahan analisis terhadap kemungkinan terjadinya gejala ini.

d. Pemantauan gerakan-gerakan angin global dan gerakan badai regional

Gerakan-gerakan angin global terjadi secara alami, ada yang terjadi karena gerak rotasi bumi, perbedaan densitas atmosfir atau perbedaan tekanan horizontal. Gerak rotasi bumi dapat menyebabkan gaya Cariolis yang mempengaruhi arah angin, sehingga gerakan udara dari tekanan tinggi ke tekanan rendah arahnya miring dan memotong isobar. Perbedaan tekanan horizontal antar tempat menyebabkan munculnya gaya gradien tekanan yang mempengaruhi gerakan udara dari tekanan tinggi ke tekanan rendah atau biasa disebut dengan angin. Gerakan-gerakan angsin sangat dipengaruhi oleh tekanan. Angin-angin siklon dan anti siklon yang mempunyai energi besar terjadi di daerah dengan tekanan udara ekstrim. Angin siklon merupakan angin gradien yang berhembus di sekitar pusat tekanan rendah, sementara angin anti siklon berhembus di sekitar pusat tekanan tinggi. Bila aktivitas manusia di berbagai tempat menyebabkan suhu di berbagai tempat berubah maka pusat-pusat tekanan akan berubah, dan bukan tidak mungkin akan terjadi lebih banyak frekuensi angin siklon dan anti siklon. Gerakan-gerakan angin ini dalam citra penginderaan jauh dapat diidentifikasi diantaranya dengan memanfaatkan citra satelit 
geosychronous GOES, Meteosat, dan SCAMS (Scanning Microwave Spektrometer).

Untuk mengetahui gerakan angin global ini dapat dilakukan dengan beberapa metode, diantaranya dengan Metode penyusunan mozaik pada foto udara, metode korelasi silang dengan menghitung koefisien korelasi silang antara dua set citra digital berurutan. Metode lainnya adalah dengan pengenalan pola. Metode mutakhir yang dapat dipakai adalah dengan SCAMS, yang menggunakan saluran gelombang mikro. Teknik yang digunakan dalam memantau gerakan angin ini adalah dengan memetakan anomali temperatur kecerahan siklon tropika yang kemudian dikorelasikan dengan tekanan sentral. Untuk menghitrung korelasi tersebut digunakan teknik analisis regresi sederhana.

e. Penginderaan daerah kutub

Daerah kutub merupakan bagian dari daerah stabilizer iklim, bila kondisi daerah kutub terganggu maka kondisi iklim di daerah lain akan terganggu. Betapa peintingnya daerah ini sehingga beberapa negara yang peduli lingkungan meluncurkan satelit untuk pemantauan daerah kutub, misalnya ERS milik negara-negara yang tergabung dalam ESA. Massa es yang berada di kutub akan menjadi ancaman terhadap masa depan umat manusia (terutama daerahdaerah pesisir dan sebagaimana diketahui bahwa banyak kota-kota strategis justru berada di daerah dekat pantai). Massa es akan mencair bila terjadi kenaikan suhu di bumi ini. Areal rutub yang luas dapat dipantau secara teliti dengan menggunakan citra satelit. Pemanfaatan berbagai spektrum, terutama spektrum $\mathbb{M}$ dan pemanfaatan gelombang mikro akan memberikan informasi kondisi massa es di daerah kutub tersebut.

f. Pemantauan lubang ozon

Keberadaan ozon sebagai lapisan filter pelindung bumi dari sengatan gelombang sinar matahari yang berbahaya saat ini berada dalam ancaman. Lubang ozon yang berhasil diidentifikasi diduga berkaitan dengan semakin banyaknya akumulasi carbon di udara. Banyak radikal bebas yang menyebabkan reaksi-rekasi yang tidak menguntungkan yang menyebabkan keberadaan ozon makin menipis. Pemantauan lubang ozon akan sulit dilaikukan hanya dengan cara terestrial. Pemanfaatan teknologi penginderaán jauh 
memungkinkan perkembangan ozon dari waktu ke waktu dapat dipantau. Dengan demikian umat manusia dapat segera memperbaiki perilakunya, demi masa depan generasi selanjutnya.

\section{Penutup}

Bumi merupakan tempat yang paling ideal untuk penyelenggaraan $k \in$ hidupan manusia dan organsime lainnya. Oleh karena itu keidealannya yang telah sedemikian rupa disetting oleh Yang Maha Kuasa perlu dijaga oleh manusia sebagai khalifah di bumi ini. Keserakahan manusia ruparupanya telah menutup panca inderanya sehingga seringkali tindakan manusia menabrak dan berusaha mengubah keberadaan hukum-hukum alam (sunatullah) tentang alam dan manusia, sehingga daya dukung dan keseimbangan alam menjadi terganggu dan dampaknya kembali menerpa manusia sendiri, bahkan kepada manusia lain yang tidak ikut mengganggu alam.

Kíini kerusakan itu telah tampak di mana-mana. Berbagai penderitaan telah dituai oleh manusia, seperti kekeringan, banjir, suhu yang semakin panas, musim yang sulit diprediksi, hantaman badai dan siklon hebat di berbagai belahan bumi, kegagalan panen karena anomali musim, dan lain-lain. Untuk mengatasi pembalasan alam terhadap perilaku rakus manusia, berbagai teknik untuk mengetahui, memantau, dan mengevaluasi kondisi bumi tempat manusia berpijak ini dikembangkan. Salah satı teknik yang sangat efektif adalah dengan analisis Citra Pengincieraan Jauh. Teknik yang kini semakin populer karena nilai aplikasinya yang sangat tinggi di berbagai bidang perlu terus dikengembangkan agar hasilnya lebih akurat dan lebih bermanfaat. Save our earth.

\section{Daftar Pustaka}

Bayong Tjasyono. 1987. Iklim dan Lingkungan. Bandung: Cendekia Jaya Utama.

Howard, John A. 1996. Penginderaan Jauh untuk Sumberdaya Hutan. Yogyakarta: Gadjahmada University Press.

Lo, CP. 1986. Applied Remote Sensing. New York: Longman Inc. 
Wisnu Arya Wardhana. 2004. Dampak Pencemaran Lingkungan. Yogyakarta: Penerbit Andi.

http://www.suarapembaruan.com/News/2007/04/11/Utama/ut01.htm. Perubahan Iklim Global Pengaruhi Pertanian.

Walhi, 2007. Perubahan iklim. Terdapat di situs www.walhi.org http://www.walhi.or.id/kampanye/energi/iklim/per_iklim_info_310 $504 /$

http://www.suarapembaruan.com/News/2007/04/12/Utama/ut01.htm www.wwf.or.id/attachment/pdf/q\&aclimate

http://www.antara.co.id/arc/2007/5/3/wwf-as-penjahat-besar-dalamperubahan-iklim/ 